\title{
ANALISIS PENGARUH KEDALAMAN FONDASI DAN SUDUT GESER TERHADAP DAYA DUKUNG FONDASI DANGKAL PADA TANAH HOMOGEN
}

\author{
Albert Kurniawan ${ }^{1}$ dan Andryan Suhendra ${ }^{2}$ \\ ${ }^{1}$ Program Studi Sarjana Teknik Sipil, Universitas Tarumanagara, Jl. Letjen S. Parman No.1 Jakarta \\ Albert.325150193@stu.untar.ac.id \\ ${ }^{2}$ Program Studi Sarjana Teknik Sipil, Universitas Tarumanagara, Jl. Letjen S. Parman No.1 Jakarta \\ andryansuhendra@yahoo.com
}

\begin{abstract}
Well-constructed foundation must be able to resist forces from the structure. Foundation bearing capacity was affected by some parameters and can be measured by various methods. Some methods that used in this study are Terzaghi, Meyerhof and finite element. The purpose of this study was to compare the bearing capacity value generated by these methods and the effect of parameters value variety against foundation bearing capacity. The parameters is foundation footing, friction angle and foundation depths. The highest value of foundation bearing capacity is generated by the finite element method. Bearing capacity that generated by finite element method experiences the biggest difference up to $41 \%$ compared to Terzaghi method and up to $26 \%$ biggest difference compared to Meyerhof method. Bearing capacity with friction angle $25^{\circ}$ is $70 \%$ greater compared to $20^{\circ}$. Meanwhile with $30^{\circ}$ increased to $220 \%$ compared to $20^{\circ}$. The value of bearing capacity differs according to the depths used. Within 1,5m depth the value of the bearing capacity is increased $35 \%$ compared to $1 \mathrm{~m}$ depths with square footing, Meanwhile with rectangle footing only increased by $32 \%$. The bearing capacity value also varies depends on the footing type. Rectangle footing was increased $9-14 \%$ compared to square footing.
\end{abstract}

Keywords: shallow foundation; bearing capacity; finite element; Meyerhof; Terzaghi

\section{ABSTRAK}

Sebuah fondasi yang baik harus bisa menahan gaya yang diberikan oleh strukturnya. Daya dukung fondasi dipengaruhi oleh beberapa parameter tanah dan dapat diukur dengan berbagai metode. Metode yang digunakan penulis adalah Terzaghi, Meyerhof dan elemen hingga. Dalam penulisan ini penulis ingin membandingkan daya dukung yang dihasilkan oleh metode-metode tersebut dan pengaruh dari variasi nilai parameter terhadap daya dukung fondasi. Parameter tersebut adalah jenis tapak, sudut geser dan kedalaman fondasi. Daya dukung terbesar dihasilkan oleh metode elemen hingga. Daya dukung yang dihasilkan oleh metode elemen hingga mengalami perbedaan terbesar hingga $41 \%$ jika dibandingkan dengan metode Terzaghi dan $26 \%$ perbedaan terbesar jika dibandingkan metode Meyerhof. Daya dukung dengan sudut geser $25^{\circ}$ lebih besar $70 \%$ jika dibandingkan dengan sudut geser $20^{\circ}$. Sedangkan pada sudut geser $30^{\circ}$ daya dukung lebih besar $220 \%$ jika dibandingkan dengan sudut geser $20^{\circ}$. Daya dukung juga berbeda tiap kedalaman fondasi. Pada kedalaman fondasi 1,5m daya dukung lebih besar 35\% jika dibandingkan pada kedalaman fondasi $1 \mathrm{~m}$ pada fondasi bujur sangkar dan pada fondasi persegi panjang lebih besar 32\%. Daya dukung juga berbeda tergantung jenis tapaknya. Pada jenis tapak fondasi persegi panjang, kapasitas daya dukung lebih besar 9 - 14\% jika dibandingkan dengan jenis tapak fondasi bujur sangkar.

Kata kunci: fondasi dangkal; daya dukung; elemen hingga; Meyerhof; Terzaghi

\section{PENDAHULUAN}

Fondasi dangkal merupakan elemen struktur yang berfungsi untuk menyalurkan beban ke tanah. Fondasi dangkal memiliki beberapa jenis seperti fondasi tapak dan menerus. Jenis tapak fondasi dangkal yang digunakan bujur sangkar dan persegi panjang. Fondasi dangkal memiliki kapasitas daya dukung. Kapasitas daya dukung dapat diperoleh dengan berbagai metode. Metode yang digunakan dalam pembahasan ini adalah metode elemen hingga Meyerhof dan Terzaghi. Batasan masalah yang dibahas yaitu jenis tapak fondasi bujur sangkar dan persegi panjang. Tanah di bawah fondasi adalah tanah lempung. Jumlah lapisan tanah satu. Faktor muka air tanah diperhitungkan. Kedalaman fondasi divariasikan. Sudut geser tanah divariasikan. Metode yang digunakan adalah metode Terzaghi dan Meyerhof. Program yang digunakan berbasis metode elemen hingga dan pemodelan didesain 
secara 3 dimensi. Tujuan dari penelitian ini adalah untuk membandingkan daya dukung fondasi dangkal pada tanah lempung dengan metode Terzaghi, Meyerhof dan elemen hingga dengan bantuan program berbasis metode elemen hingga.

\section{Fondasi dangkal}

Bagian terendah dari suatu struktur biasanya disebut sebagai fondasi. Fungsi fondasi adalah untuk memindahkan beban dari struktur ke tanah yang menjadi tumpuannya. Sebuah fondasi yang baik adalah fondasi yang memindahkan beban ke tanah tanpa menimbulkan tekanan yang berlebihan pada tanah. Menurut Terzaghi (1943) dalam Das (2007) sebuah fondasi dikategorikan fondasi dangkal bila kedalaman fondasi kurang dari atau sama dengan lebar dari fondasi tersebut. Namun, para peneliti kemudian menyarankan bahwa fondasi dengan kedalaman 3 sampai 4 kali lebar fondasi dikategorikan sebagai fondasi dangkal.

\section{Daya dukung fondasi dangkal Terzaghi}

Persamaan daya dukung untuk fondasi menerus menurut Terzaghi (1943) dalam Das (2007) dinyatakan sebagai berikut:

- Fondasi menerus:

$$
q u=c N c+D f \cdot \gamma \cdot N q+0,5 \gamma \cdot B \cdot N \gamma
$$

- Fondasi bujur sangkar:

$$
q u=1,3 c N c+D f \cdot \gamma \cdot N q+0,4 \gamma \cdot B \cdot N \gamma
$$

dengan $\mathrm{qu}=$ daya dukung batas, $\mathrm{c}=$ kohesi tanah, $\mathrm{Nc}, \mathrm{Nq}, \mathrm{N} \gamma=$ faktor daya dukung Terzaghi, Df = kedalaman fondasi, $\gamma=$ berat volume tanah dan $\mathrm{B}=$ lebar fondasi.

Nilai dari faktor daya dukung Terzaghi adalah fungsi dari besarnya sudut geser dalam yang diberikan Terzaghi dalam bentuk grafik pada gambar berikut:

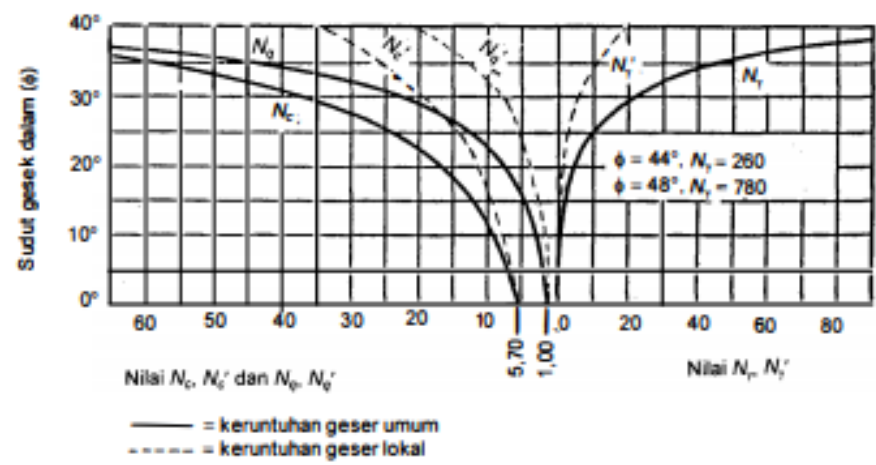

Gambar 1. Hubungan sudut geser dalam dengan faktor daya dukung Terzaghi (Sumber: Hardiyatmo,1996)

\section{Daya dukung fondasi dangkal Meyerhof}

Meyerhof (1963) dalam Bowles (1992) memberikan persamaan daya dukung yang mirip dengan persamaan Terzaghi tetapi dengan menambahkan suatu faktor yaitu faktor bentuk, faktor kedalaman dan faktor kemiringan yang dapat dilihat pada persamaan sebagai berikut:

- Beban vertikal:

$$
q u=c N c S c D c+D f \cdot \gamma \cdot N q S q D q+0,5 \gamma \cdot B \cdot N \gamma S \gamma D \gamma
$$

- Beban miring:

$$
q u=c N c D c I c+D f \cdot \gamma \cdot N q D q I q+0,5 \gamma \cdot B \cdot N \gamma D \gamma I \gamma
$$

dengan $\mathrm{qu}=$ daya dukung batas, $\mathrm{c}=$ kohesi tanah, $\mathrm{Nc}, \mathrm{Nq}, \mathrm{N} \gamma=$ faktor daya dukung Meyerhof, Dc,Dq,D $\gamma=$ faktor kedalaman, Ic,Iq,I $\gamma=$ faktor kemiringan, $\mathrm{Df}=$ kedalaman fondasi, $\gamma=$ berat volume tanah dan $\mathrm{B}=$ lebar fondasi. 


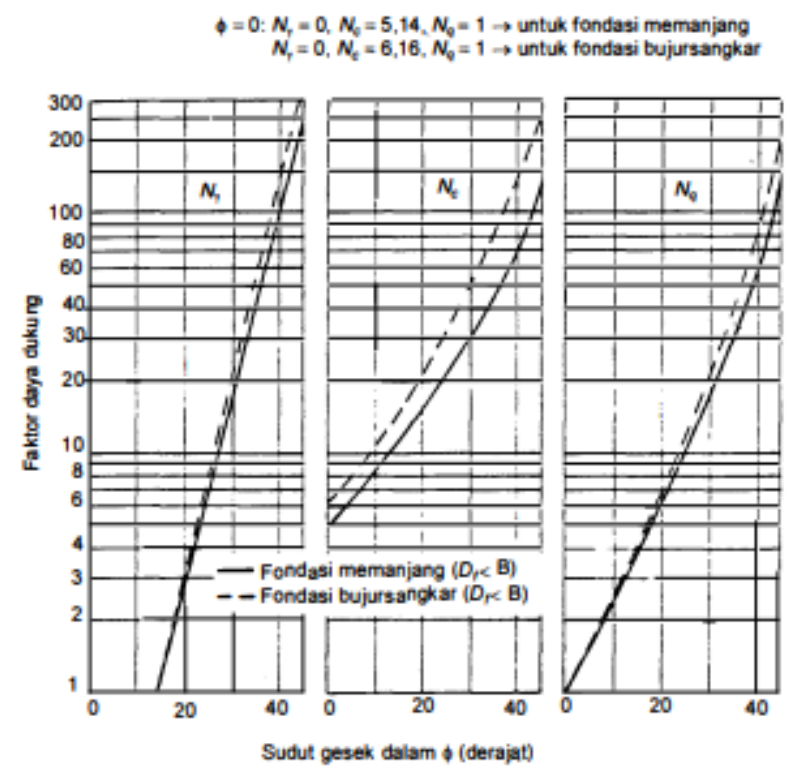

Gambar 2. Hubungan sudut geser dalam dengan faktor daya dukung Meyerhof (Sumber: Hardiyatmo,1996)

\section{Metode elemen hingga}

Desai dan Christian (1977) telah melakukan studi dengan membandingkan besarnya tegangan terhadap perpindahan model laboratorium dengan model matematik menggunakan metode elemen hingga. Hasil dari studi tersebut menunjukkan bahwa metode elemen hingga dapat memberikan hasil yang memuaskan untuk memprediksi tegangan dan deformasi yang terjadi. Analisis menggunakan metode elemen hingga dilakukan dengan bantuan program berbasis metode elemen hingga 3 dimensi. Langkah-langkah yang dilakukan adalah menentukan model geometri, menentukan model material, menentukan parameter material yang digunakan dan melakukan kalkulasi. Program secara otomatis akan membagi tanah menjadi elemen-elemen segitiga. Output yang dihasilkan diantaranya model mesh geometri, kurva $\sum$ Mstage, kurva $\sum \mathrm{M} s f$ dan daya dukung batas.

\section{Pengaruh muka air tanah terhadap daya dukung}

Meyerhof (1965) dalam Budhu (2010) menyatakan bahwa tidak ada koreksi yang harus diterapkan pada nilai faktor daya dukung untuk efek air tanah. Namun, berat volume tanah dipengaruhi oleh kadar air dan kedudukan air tanah. Oleh karena itu, Letak muka air tanah dapat mempengaruhi daya dukung tanah tergantung pada letaknya. Pengaruh muka air tanah terhadap daya dukung tanah :

- Muka air tanah berada sangat dalam

Apabila muka air tanah sangat dalam dibandingkan dengan lebar fondasinya atau $\mathrm{z}>\mathrm{B}$, dimana $\mathrm{z}$ adalah jarak muka air tanah di bawah dasar fondasi. Maka nilai berat volume tanah yang digunakan adalah berat volume tanah dengan kondisi basah. Pada kondisi ini, Parameter kuat geser yang digunakan dalam perhitungan adalah parameter kuat geser dalam tinjauan tegangan efektif.

- Muka air tanah berada di atas dasar fondasi

Apabila muka air tanah berada di atas atau sama dengan dasar fondasi, maka nilai dari berat volume yang dipakai adalah berat volume efektif. Karena zona geser yang terletak di bawah fondasi sepenuhnya terendam air.

- Muka air tanah berada di bawah dasar fondasi

Apabila muka air tanah terletak pada kedalaman $\mathrm{z}$ di bawah dasar fondasi atau $\mathrm{z}<\mathrm{B}$, maka berat volume tanah yang digunakan adalah kondisi basah ataupun kering tergantung pada kondisi tanah tersebut. Akibat massa tanah dalam zona geser sebagian terendam air, berat volume tanah yang digunakan adalah berat volume tanah rata-rata.

\section{Penurunan}

Penurunan adalah pengurangan volume tanah sebagai konsekuensi dari peningkatan tegangan efektif. Penurunan terdiri dari beberapa atau jumlah dari penurunan langsung, penurunan konsolidasi dan penurunan sekunder. Penurunan digunakan ketika tegangan total konstan dan zona tanah yang terlibat atau terpengaruh tetap berada 
sama sementara tegangan efektif meningkat (Felenius,2014). Hough (1959) dalam Conduto (2001) menekankan bahwa daya dukung dan penurunan tidak berjalan seiring,

\section{METODE PENELITIAN}

\section{Pengumpulan data}

Kajian teknis kali ini berada di salah satu proyek di Jakarta. Data yang dikumpulkan adalah berdasarkan hasil peninjauan di lokasi proyek dengan mengumpulkan hasil uji tanah yang telah dilakukan. Data yang dikumpulkan adalah data hasil tes SPT (Standart Penetration Test) dan hasil uji laboratorium.

\section{Pengelolaan data}

Metode pengelolaan data yang dilakukan untuk menganalisa data menggunakan rumus Terzaghi, Meyerhof dan dengan program berbasis metode elemen hingga. Analisis akan dilakukan pada jenis tapak fondasi yang berbeda, sudut geser yang berbeda dan kedalaman fondasi yang berbeda. Hasil analisis berupa daya dukung batas dan hubungan antara pembebanan dengan penurunan elastis. Kemudian hasil analisis tersebut dibandingkan berdasarkan jenis tapak fondasi, variasi sudut geser dan variasi kedalaman fondasi.

\section{Diagram alir}

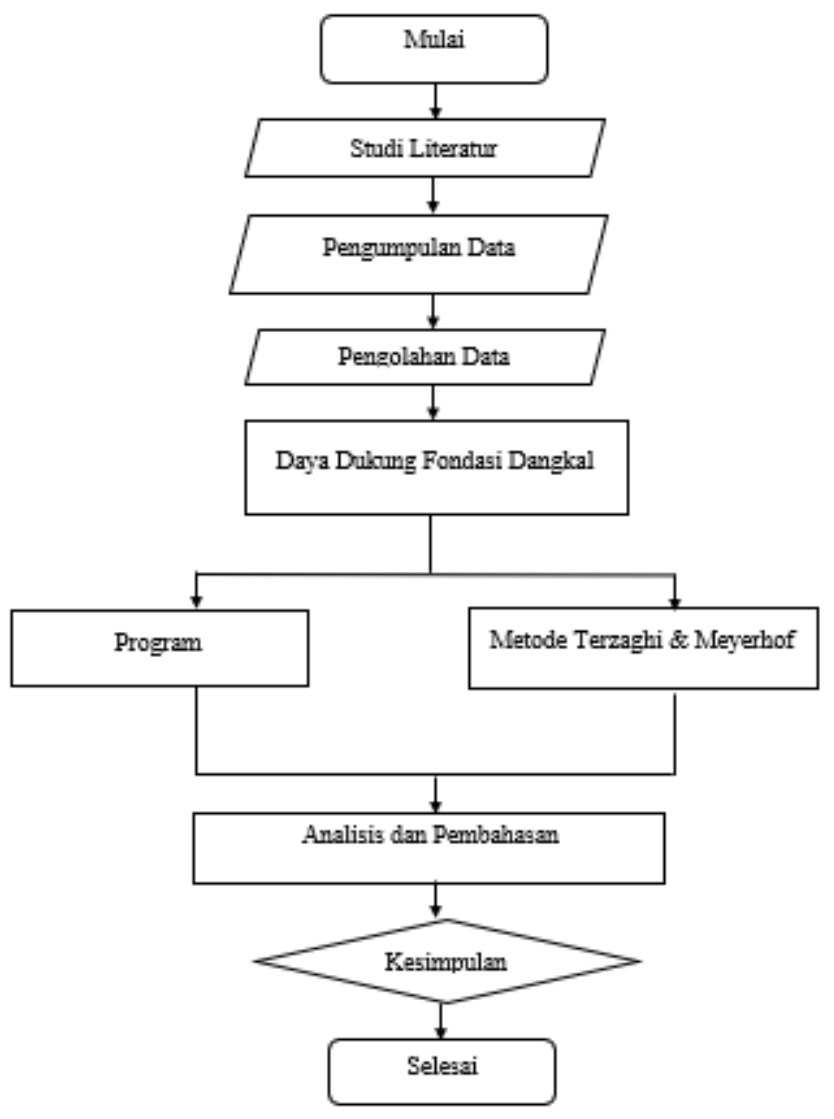

Gambar 3. Diagram alir penelitian

\section{HASIL DAN PEMBAHASAN}

\section{Data fondasi}

Fondasi dangkal yang digunakan adalah beton tidak bertulang dengan berat jenis $22 \mathrm{KN} / \mathrm{m}^{3}$ dan mutu beton fc' 28 $\mathrm{MPa}$. Jenis tapak fondasi yang digunakan adalah bujur sangkar dan persegi panjang dengan luas $10.000 \mathrm{~cm}^{2}$. Panjang dan lebar fondasi yaitu pada bujur sangkar 100x100 cm dan pada persegi panjang $125 \times 80 \mathrm{~cm}$ dengan kedalaman fondasi yang divariasikan. Kedalaman fondasi yang digunakan adalah $1 \mathrm{~m}$ dan 1,5m. Digunakan rumus $4700 \sqrt{f c^{\prime}}$ yang terdapat pada SNI 8460:2017 untuk memperoleh nilai modulus elastisitas dari fondasi tersebut. 
- $\mathrm{E} \quad=4700 \sqrt{f c^{\prime}}$

$=4700 \sqrt{28}$

$=24870,06232 \mathrm{Mpa}$

- $\mathrm{A}_{\text {bujur sangkar }}=B x L$

$$
=100 \mathrm{~cm} \times 100 \mathrm{~cm}
$$

$=10.000 \mathrm{~cm}^{2}$

- $\mathrm{A}_{\text {bujur sangkar }}=B x L$

$$
\begin{aligned}
& =100 \mathrm{~cm} \times 100 \mathrm{~cm} \\
& =10.000 \mathrm{~cm}^{2}
\end{aligned}
$$

\section{Parameter tanah}

Parameter tanah didapatkan berdasarkan hasil korelasi dari data tanah yang tersedia. Adapun ringkasan parameter

\begin{tabular}{|c|c|c|c|c|c|c|c|}
\hline $\begin{array}{c}\text { Kedalaman } \\
\text { (m) }\end{array}$ & $\mathrm{N}_{\mathrm{SPT}}$ & Tipe Tanah & $\begin{array}{c}\text { Konsistensi } \\
\text { Tanah }\end{array}$ & $\begin{array}{c}\gamma_{s a t} \\
\left(\mathrm{kN} / \mathrm{m}^{3}\right)\end{array}$ & $\begin{array}{c}\mathrm{c}^{\prime} \\
\left(\mathrm{kN} / \mathrm{m}^{2}\right)\end{array}$ & $\begin{array}{c}E^{\prime} \\
\left(\mathrm{kN} / \mathrm{m}^{2}\right)\end{array}$ & e \\
\hline $0-6$ & 3 & Lempung & Lunak & 16 & 4 & 3200 & 0,9 \\
\hline
\end{tabular}
tanah yang digunakan dalam penelitian ini dapat dilihat pada tabel 1 berikut:

Tabel 1. Ringkasan parameter tanah

\section{Metode elemen hingga}

Berdasarkan hasil analisis yang dilakukan menggunakan program terdapat beberapa output yang diperoleh sebagai berikut:

- Kurva $\Sigma$ Mstage

Untuk memperoleh nilai daya dukung ultimate, kurva harus menyentuh angka 1. Jika kurva tidak menyentuh angka 1, Artinya beban yang dimasukkan terlalu besar sehingga menyebabkan runtuhnya tanah. Hal ini dapat dilihat pada gambar 4 .

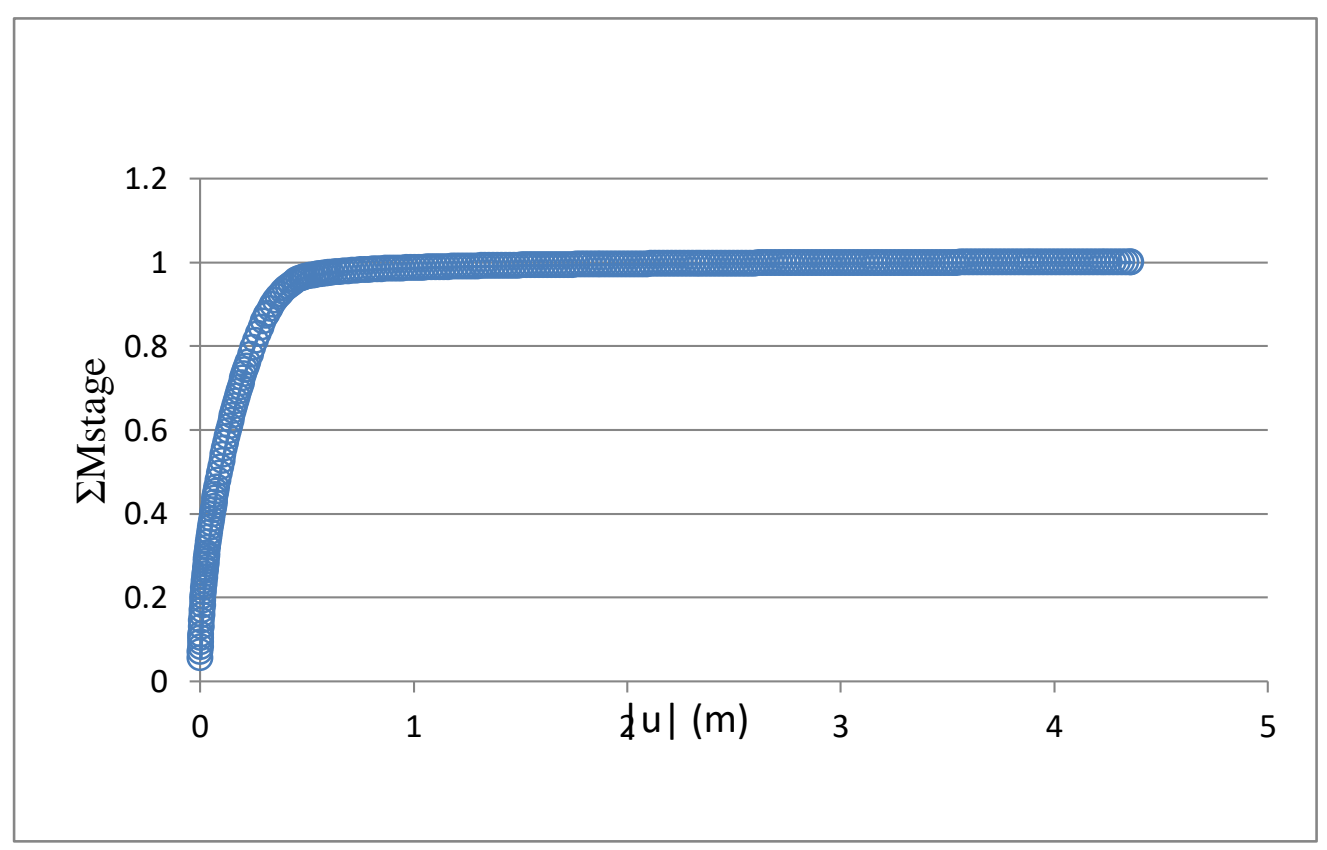

Gambar 4. Grafik इMstage 
- Kurva $\Sigma \mathrm{M} s f$

Dalam perhitungan ini, kurva harus sedekat mungkin dengan angka 1 dan kurva harus konstan pada bagian ujungnya. Semakin dekat kurva dengan angka 1 semakin tepat hasil dari daya dukung pada program. Hal ini dapat dilihat pada gambar 5 .

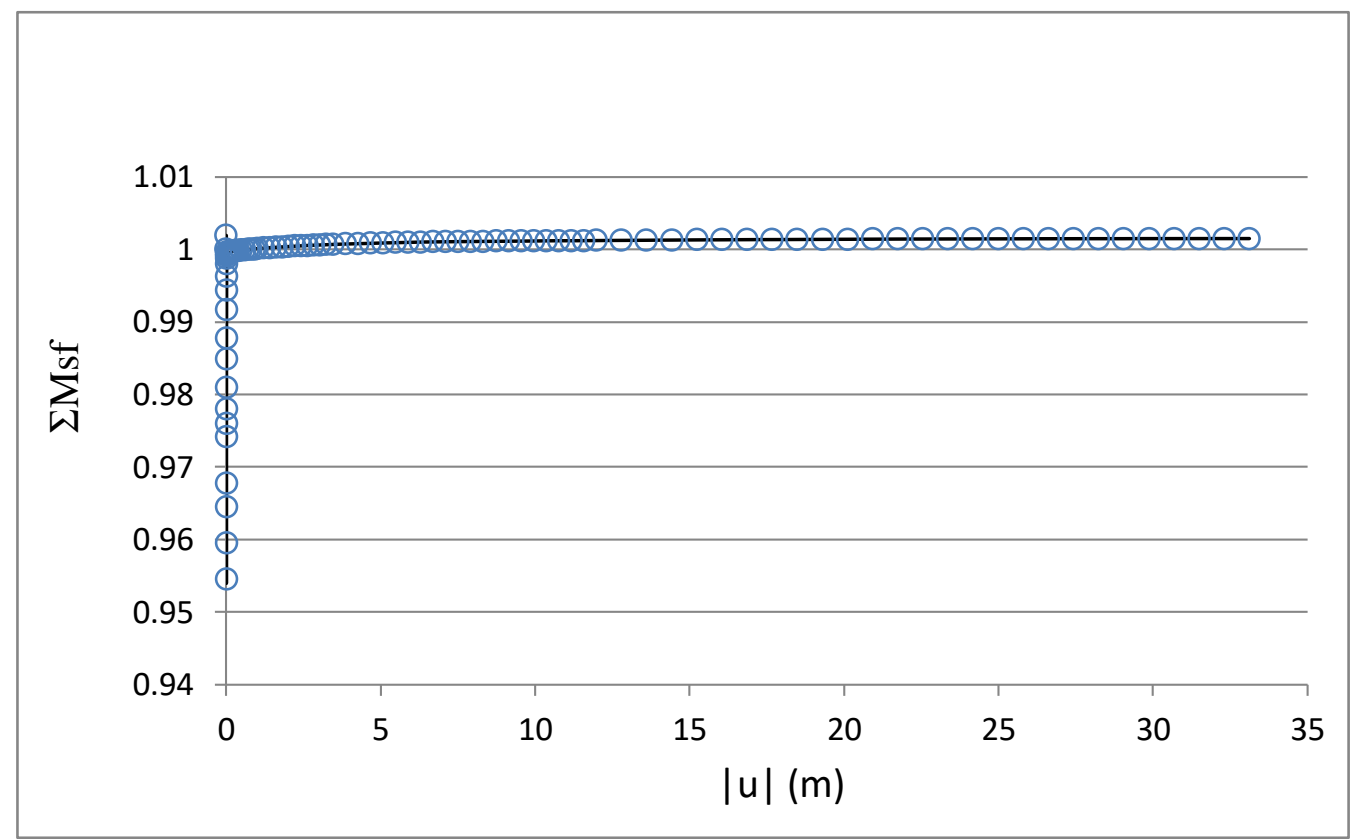

Gambar 5. Grafik $\Sigma \mathrm{M} s f$

- Daya dukung ultimate

Berdasarkan hasil analisis metode elemen hingga dengan bantuan program, maka ringkasan nilai dari daya dukung batas dapat dilihat pada tabel 2 berikut:

Tabel 2. Daya dukung batas metode elemen hingga

\begin{tabular}{ccccc}
\hline Jenis tapak & Sudut geser $\left({ }^{\mathbf{0}}\right)$ & Df $(\mathbf{m})$ & $\mathbf{q u}\left(\mathbf{k N} / \mathbf{m}^{\mathbf{2}}\right)$ & Msf \\
\hline \multirow{2}{*}{ Fondasi bujur sangkar (100x100) } & 20 & 1 & 372 & 1,042 \\
& 25 & 1 & 622 & 1,030 \\
& 30 & 1 & 1022 & 1,046 \\
& 20 & 1,5 & 512 & 1,009 \\
& 25 & 1,5 & 842 & 1,008 \\
& 30 & 1,5 & 1422 & 1,009 \\
\hline \multirow{3}{*}{ Fondasi persegi panjang (125x80) } & 20 & 1 & 392 & 1,002 \\
& 25 & 1 & 632 & 1,008 \\
& 30 & 1 & 1052 & 1,015 \\
& 20 & 1,5 & 522 & 1,004 \\
& 25 & 1,5 & 852 & 1,008 \\
& 30 & 1,5 & 1442 & 1,007
\end{tabular}




\section{Metode Terzaghi dan Meyerhof}

Perhitungan manual dilakukan dengan menggunakan rumus Terzaghi dan Meyerhof pada fondasi bujur sangkar, Sedangkan pada fondasi persegi panjang menggunakan rumus Meyerhof. Rumus Terzaghi dan Meyerhof yang digunakan untuk perhitungan dapat dilihat pada persamaan 1 sampai dengan persamaan 4. Ringkasan hasil analisis daya dukung dapat dilihat pada tabel 3 berkut:

Tabel 3. Ringkasan daya dukung Terzaghi dan Meyerhof

\begin{tabular}{ccccc}
\hline Jenis tapak & Sudut geser $\left.\mathbf{(}^{\mathbf{0}}\right)$ & Df $(\mathbf{m})$ & Meyerhof $\left(\mathbf{k N} / \mathbf{m}^{\mathbf{2}}\right)$ & Terzaghi $\left(\mathbf{k N} / \mathbf{m}^{\mathbf{2}}\right)$ \\
\hline 20 & 1 & 279,86 & 242,44 \\
Bujur sangkar & 25 & 1 & 486,62 & 395,8 \\
$(100 x 100)$ & 20 & 1 & 899,92 & 679,52 \\
& 25 & 1,5 & 377,41 & 301,64 \\
& 30 & 1,5 & 659,34 & 497,4 \\
& 20 & 1 & 1221,67 & 859,52 \\
Persegi & 25 & 1 & 311,96 & \\
panjang & 30 & 1 & 554,96 & \\
$(125 x 80)$ & 20 & 1,5 & 412,02 & \\
& 25 & 1,5 & 734,46 & \\
\hline
\end{tabular}

Perbandingan perhitungan daya dukung batas Terzaghi dan Meyerhof dengan metode elemen hingga

Berdasarkan hasil analisis dari perbandingan hasil perhitungan daya dukung ultimate metode Terzaghi dan Meyerhof dengan metode elemen hingga dengan bantuan program, maka dapat disimpulkan bahwa nilai dari daya dukung ultimate yang dihasilkan oleh metode elemen hingga dengan bantuan program selalu lebih besar dibandingkan nilai daya dukung ultimate dengan metode Terzaghi dan Meyerhof. Hal ini dapat dilihat pada tabel 4 dan 5 .

Tabel 4. Perbandingan daya dukung batas Terzaghi dan Meyerhof dengan elemen hingga pada fondasi bujur sangkar

\begin{tabular}{ccccccc}
\hline $\begin{array}{c}\text { Sudut } \\
\text { geser } \\
(\mathbf{0})\end{array}$ & Df $(\mathbf{m})$ & \multicolumn{3}{c}{ Daya Dukung $\left(\mathbf{k N} / \mathbf{m}^{\mathbf{2}}\right)$} & \multicolumn{2}{c}{$\begin{array}{c}\text { Perbedaan Program dengan } \\
(\boldsymbol{\%})\end{array}$} \\
\cline { 5 - 7 } \cline { 5 - 7 } & & Meyerhof & Terzaghi & Program & Meyerhof & Terzaghi \\
\hline 20 & 1 & 279,86 & 242,44 & 372 & 24,77 & 34,83 \\
25 & 1 & 486,62 & 395,8 & 622 & 21,76 & 36,37 \\
30 & 1 & 899,92 & 679,52 & 1022 & 11,94 & 33,51 \\
20 & 1,5 & 377,41 & 301,64 & 512 & 26,29 & 41,09 \\
25 & 1,5 & 659,34 & 497,4 & 842 & 21,69 & 40,93 \\
30 & 1,5 & 1221,67 & 859,52 & 1422 & 14,09 & 39,56 \\
\hline
\end{tabular}


Tabel 5. Perbandingan daya dukung batas Terzaghi dan Meyerhof dengan elemen hingga pada fondasi persegi panjang

\begin{tabular}{|c|c|c|c|c|}
\hline Sudut geser $\left({ }^{0}\right)$ & $\begin{array}{l}\text { Df } \\
(\mathbf{m})\end{array}$ & $\begin{array}{c}\text { Daya Dukung } \\
\text { Meyerhof }\left(k N / \mathbf{m}^{2}\right)\end{array}$ & $\begin{array}{c}\text { Daya Dukung } \\
\text { Program } \\
\left(\mathbf{k N} / \mathbf{m}^{2}\right) \\
\end{array}$ & $\begin{array}{c}\text { Perbedaan } \\
\text { Program dengan } \\
\text { Meyerhof }(\%) \\
\end{array}$ \\
\hline 20 & 1 & 311,96 & 392 & 20,42 \\
\hline 25 & 1 & 554,96 & 632 & 12,19 \\
\hline 30 & 1 & 1052,68 & 1052 & 0,06 \\
\hline 20 & 1,5 & 412,02 & 522 & 21,07 \\
\hline 25 & 1,5 & 734,46 & 852 & 13,80 \\
\hline 30 & 1,5 & 1392,08 & 1442 & 3,46 \\
\hline
\end{tabular}

\section{Perbandingan daya dukung batas terhadap sudut geser}

Berdasarkan hasil analisis perbandingan daya dukung ultimate terhadap variasi nilai sudut geser, maka dapat disimpulkan bahwa semakin besar nilai sudut geser, Maka semakin besar pula nilai dari daya dukung ultimate dan penurunan elastisnya. Selain itu dapat disimpulkan juga bahwa semakin besar nilai sudut geser, Maka semakin kecil nilai dari persentase perbedaan antara perhitungan metode Terzaghi dan Meyerhof dengan metode elemen hingga dengan bantuan program. Hal ini dapat dilihat pada gambar di bawah.

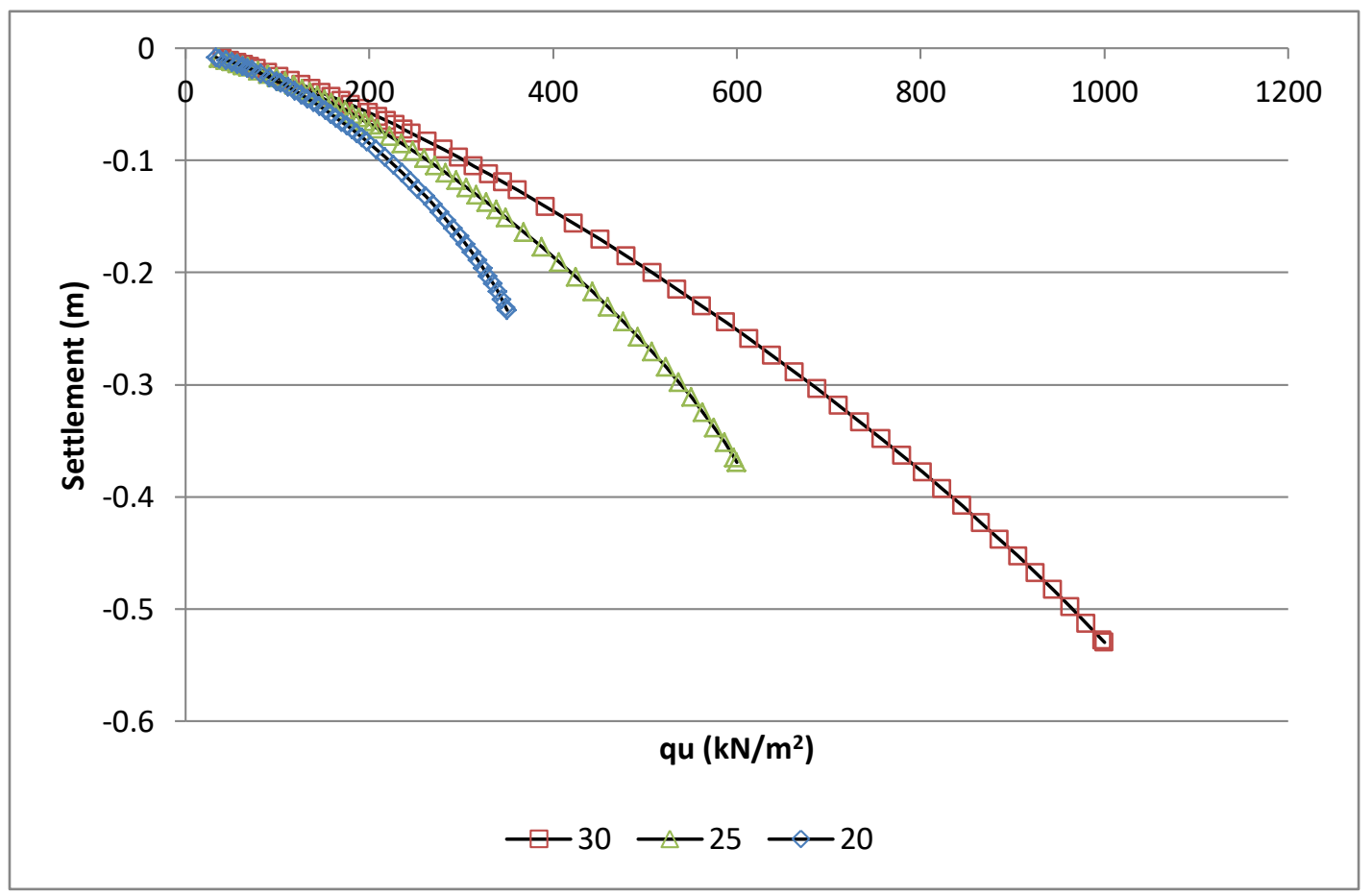

Gambar 6. Grafik perbandingan pengaruh variasi nilai sudut geser pada fondasi bujur sangkar dengan kedalaman 1 


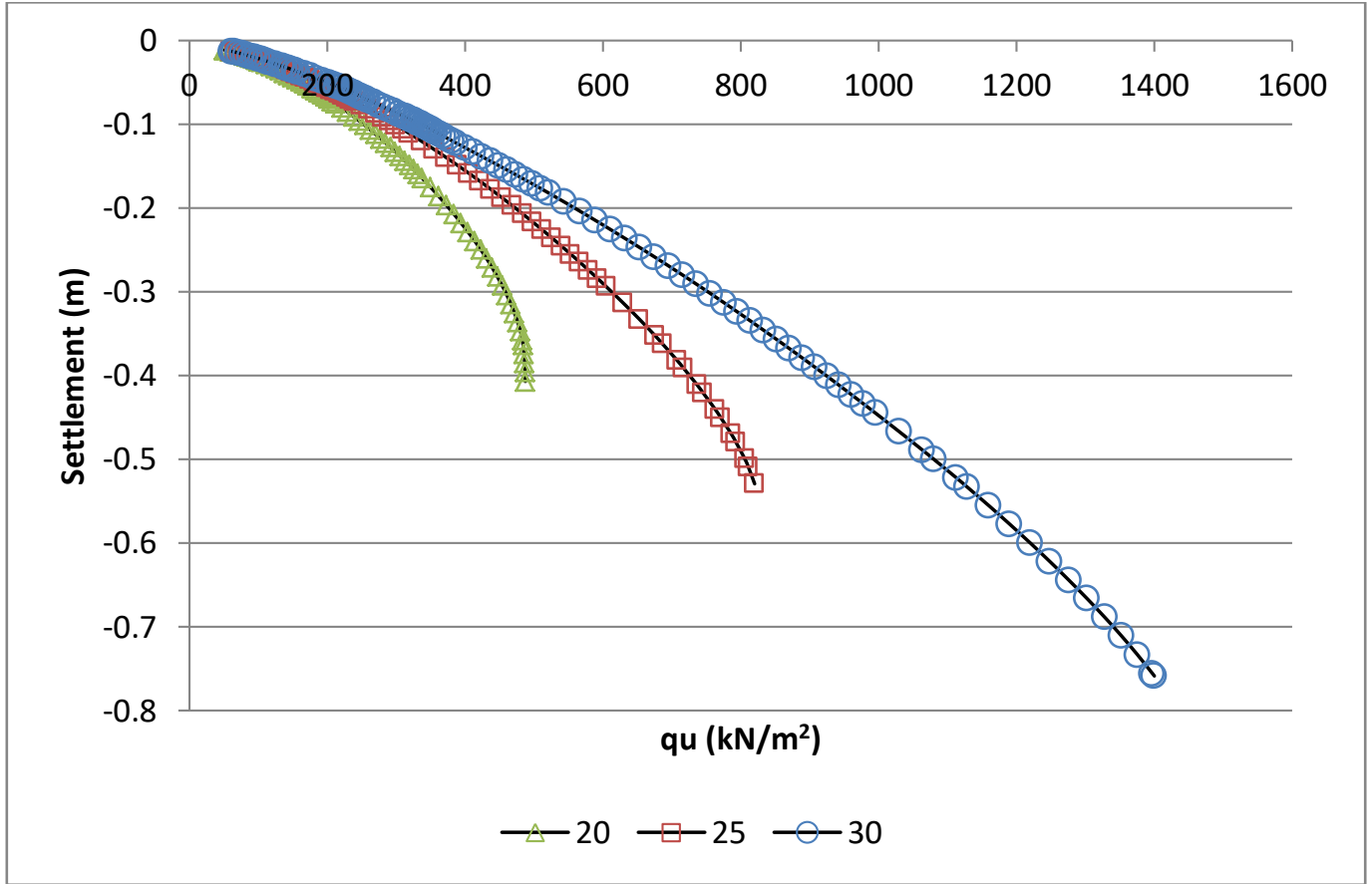

Gambar 7. Grafik perbandingan pengaruh variasi nilai sudut geser pada fondasi bujur sangkar dengan kedalaman $1,5 \mathrm{~m}$

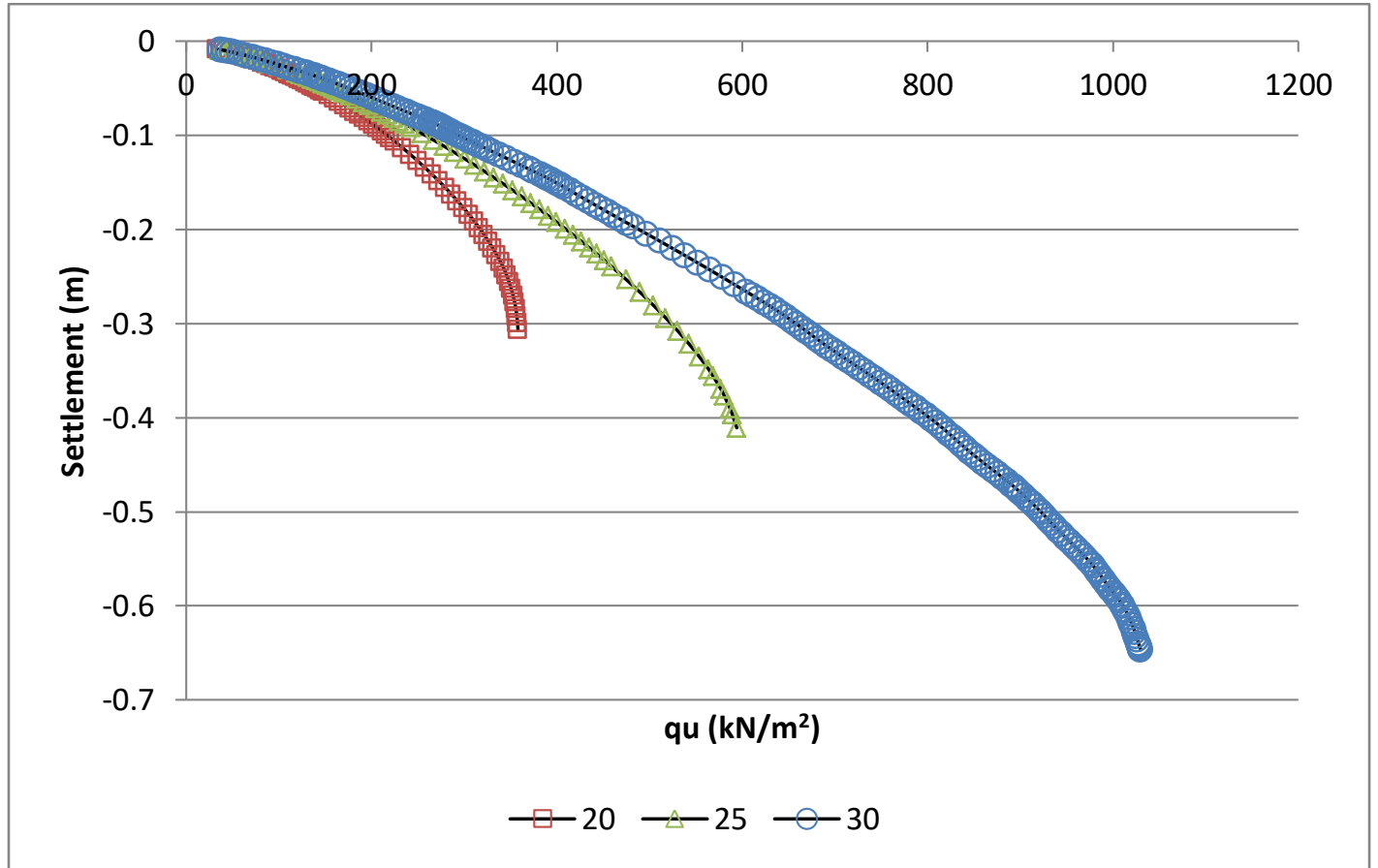

Gambar 8. Grafik perbandingan pengaruh variasi nilai sudut geser pada fondasi persegi panjang dengan kedalaman $1 \mathrm{~m}$ 


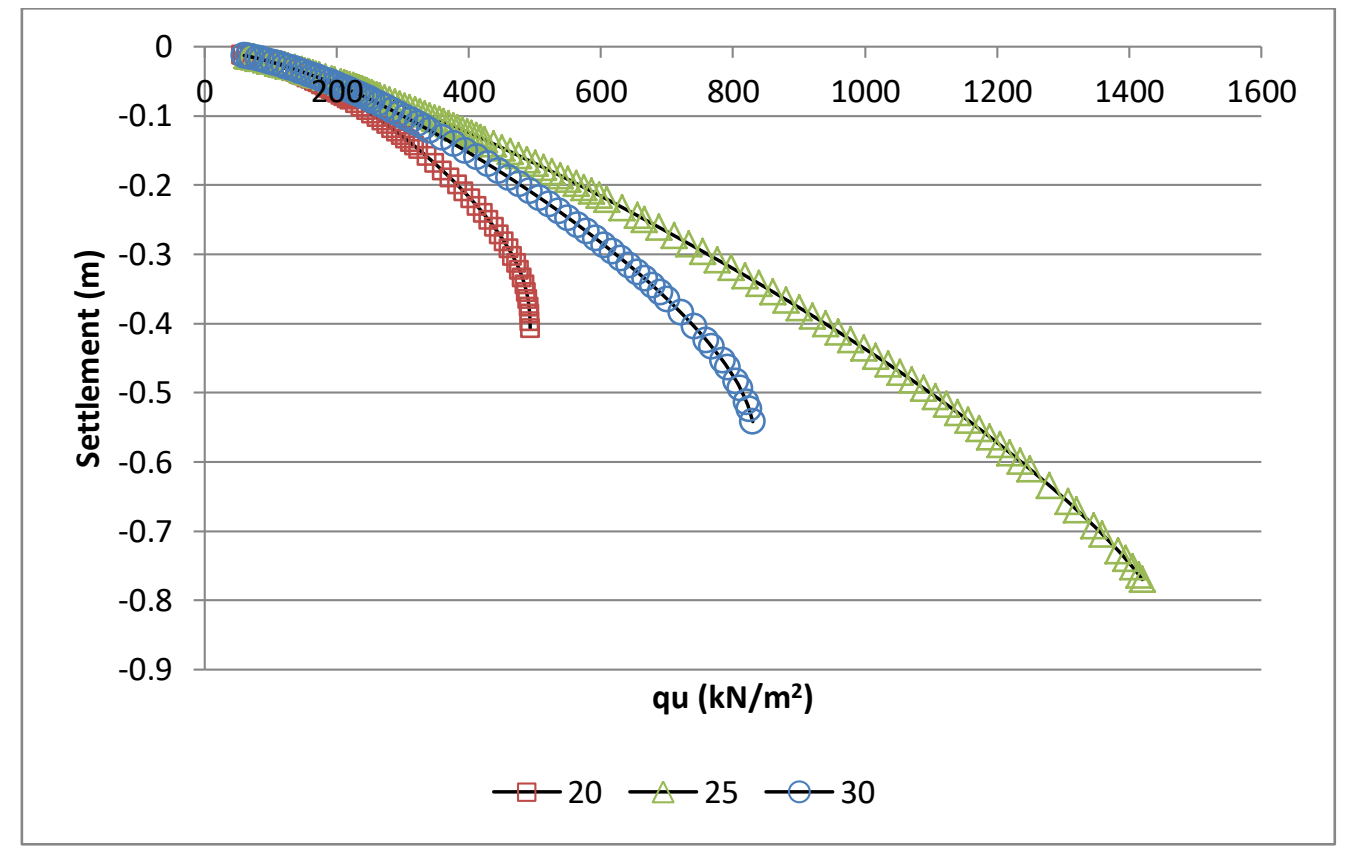

Gambar 9. Grafik perbandingan pengaruh variasi nilai sudut geser pada fondasi persegi panjang dengan kedalaman $1,5 \mathrm{~m}$

\section{Perbandingan daya dukung batas terhadap kedalaman fondasi}

Berdasarkan hasil analisis perbandingan nilai daya dukung ultimate dengan variasi nilai kedalaman fondasi, maka dapat disimpulkan bahwa semakin dalam sebuah fondasi, Semakin besar pula nilai daya dukung ultimate dan penurunan elastisnya. Hal ini dapat dilihat pada gambar 10 dan 11.

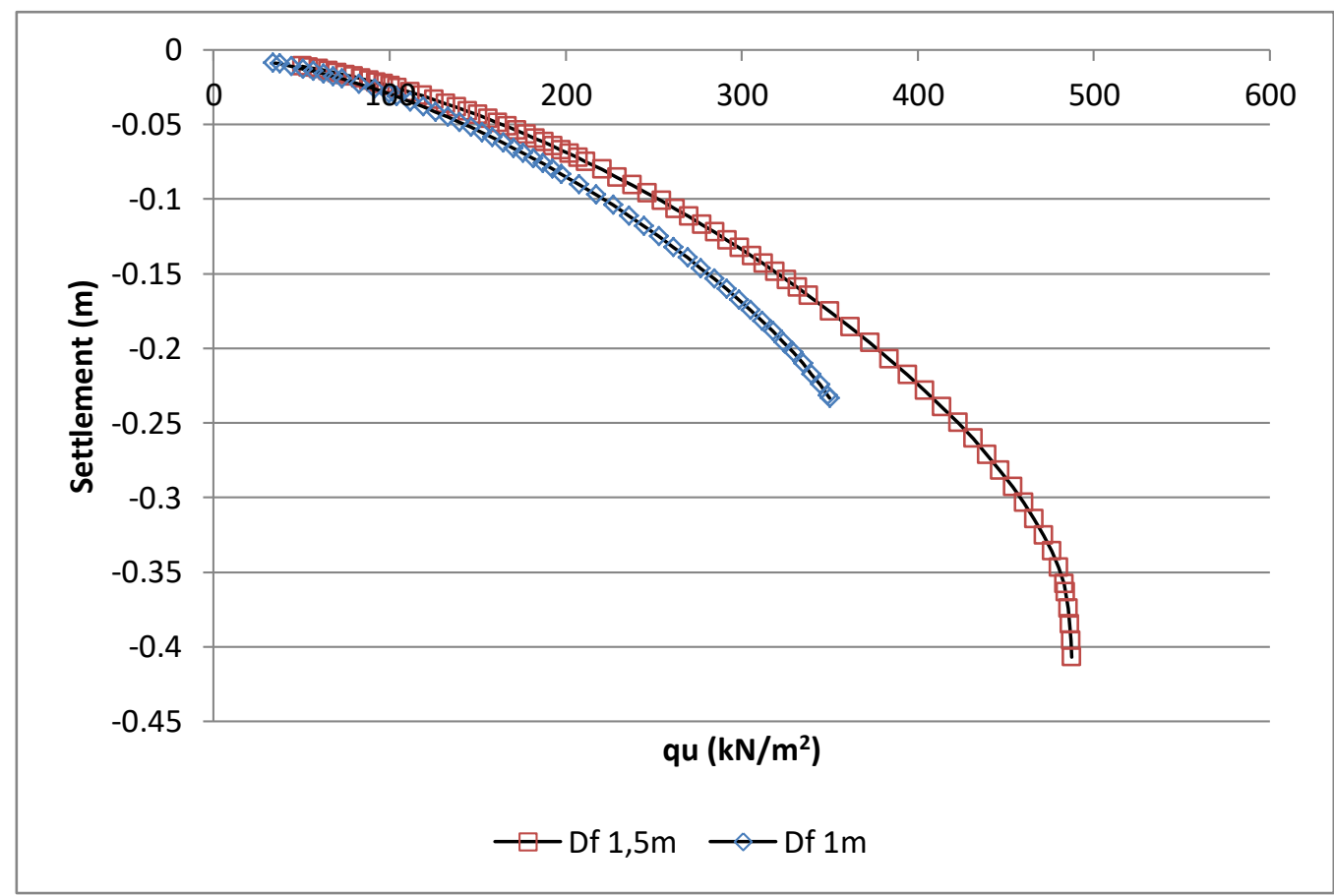

Gambar 10. Grafik perbandingan pengaruh variasi kedalaman pada fondasi bujur sangkar 


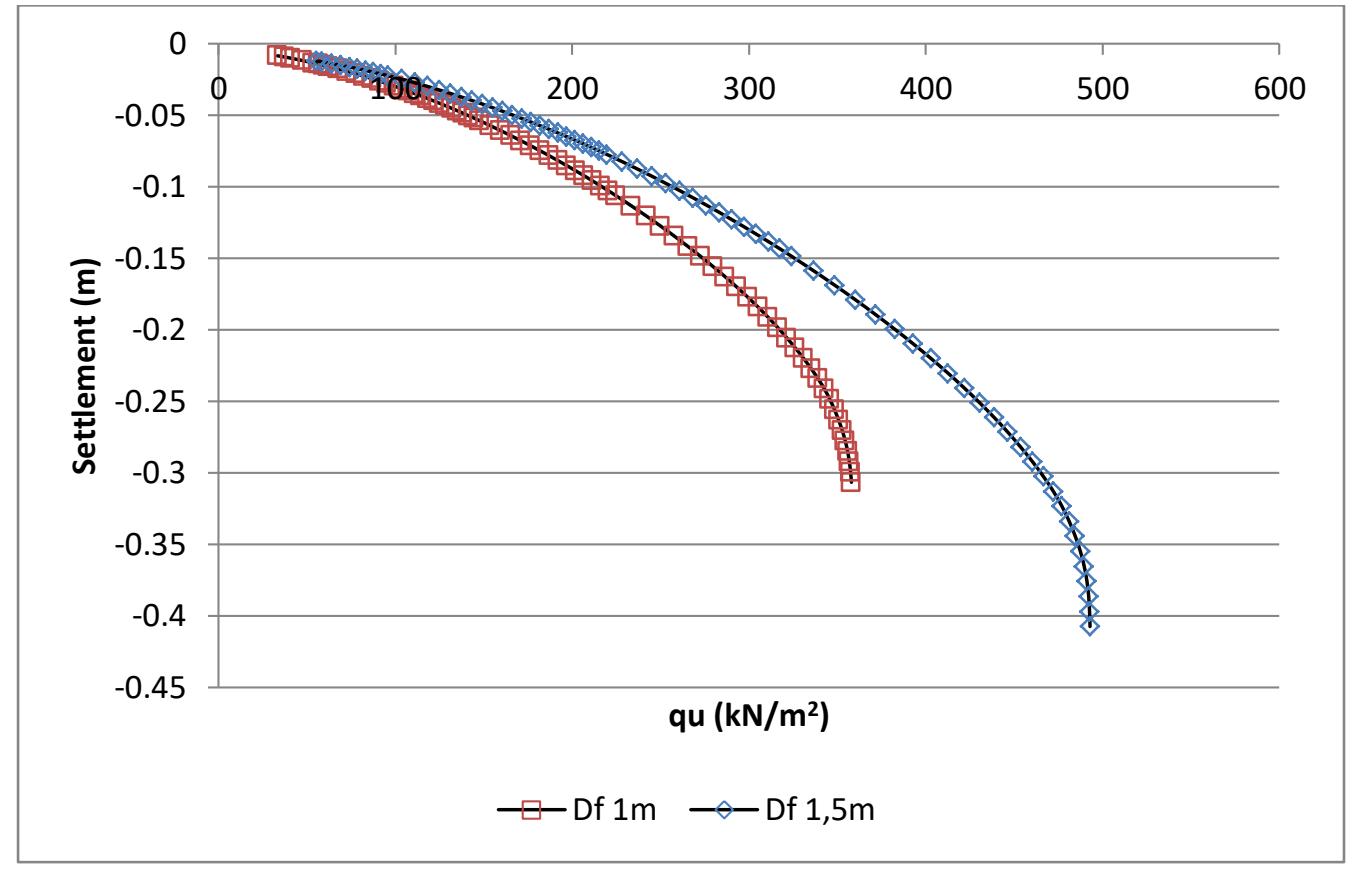

Gambar 11. Grafik perbandingan pengaruh variasi kedalaman pada fondasi persegi panjang

\section{Perbandingan daya dukung batas terhadap bentuk tapak fondasi}

Berdasarkan hasil analisis perbandingan nilai daya dukung ultimate terhadap bentuk tapak fondasi dengan luas yang sama, dapat disimpulkan bahwa nilai daya dukung ultimate dan besar penurunan elastis yang dihasilkan tidak berbeda jauh atau hampir sama. Bentuk tapak fondasi dengan luas yang sama tidak menyebabkan perbedaan yang besar. Hal ini dapat dilihat pada gambar 12.

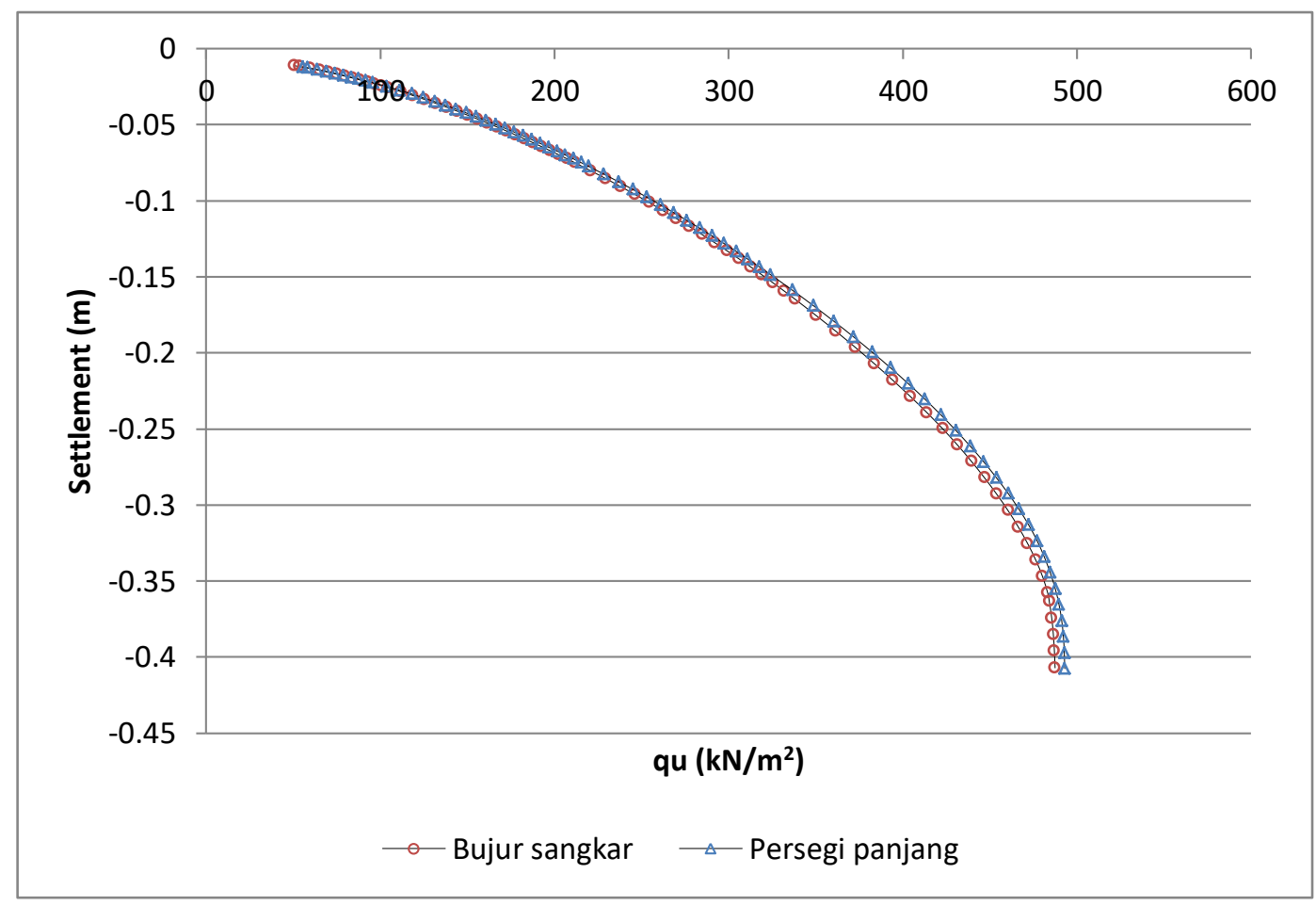

Gambar 12. Grafik perbandingan pengaruh bentuk tapak fondasi 


\section{Perbandingan penurunan elastis ditinjau pada tepi dan tengah fondasi}

Berdasarkan hasil analisis perbandingan penurunan elastis pada tepi dan tengah fondasi, maka dapat disimpulkan bahwa terdapat perbedaan yang sangat kecil dengan persentase perbedaan kurang dari $1 \%$. Hal ini dapat dilihat pada tabel 6 dan 7 .

Tabel 6. Perbandingan penurunan elastis ditinjau pada tepi dan tengah fondasi pada fondasi bujur sangkar

\begin{tabular}{cccccc}
\hline \multirow{2}{*}{ Jenis tapak } & \multirow{2}{*}{ Sudut geser $\left(\mathbf{(}^{\mathbf{*}}\right)$} & $\begin{array}{c}\text { Df } \\
(\mathbf{m})\end{array}$ & \multicolumn{2}{c}{ Penurunan elastis (m) } & \multirow{2}{*}{ Perbedaan (\%) } \\
\cline { 5 - 6 } & 20 & 1 & $-0,23334$ & $-0,23465$ & 0,55869 \\
& 25 & 1 & $-0,36904$ & $-0,37091$ & 0,50435 \\
\multirow{2}{*}{ Fondasi bujur sangkar (100x100) } & 30 & 1 & $-0,52963$ & $-0,53151$ & 0,35344 \\
& 20 & 1,5 & $-0,40703$ & $-0,40822$ & 0,29201 \\
& 25 & 1,5 & $-0,52924$ & $-0,53066$ & 0,26655 \\
& 30 & 1,5 & $-0,75872$ & $-0,76094$ & 0,29129 \\
\hline
\end{tabular}

Tabel 7. Perbandingan penurunan elastis ditinjau pada tepi dan tengah fondasi pada fondasi persegi panjang

\begin{tabular}{cccccc}
\hline \multirow{2}{*}{ Jenis tapak } & \multirow{2}{*}{ Sudut geser $\left({ }^{\mathbf{0}}\right)$} & \multirow{2}{*}{$\begin{array}{c}\text { Df } \\
(\mathbf{m})\end{array}$} & \multicolumn{2}{c}{ Penurunan elastis (m) } & \multirow{2}{*}{ Perbedaan (\%) } \\
\cline { 5 - 6 } & 20 & 1 & $-0,30663$ & $-0,30792$ & 0,41875 \\
& 25 & 1 & $-0,41080$ & $-0,41253$ & 0,41841 \\
\multirow{2}{*}{ Fondasi persegi panjang (125x80) } & 30 & 1 & $-0,64666$ & $-0,65070$ & 0,62209 \\
& 20 & 1,5 & $-0,40751$ & $-0,40762$ & 0,02701 \\
& 25 & 1,5 & $-0,54187$ & $-0,54210$ & 0,04293 \\
& 30 & 1,5 & $-0,77020$ & $-0,77014$ & 0,00873 \\
\hline
\end{tabular}

\section{KESIMPULAN DAN SARAN}

\section{Kesimpulan}

Berdasarkan kajian teknis, analisis, dan pembahasan variasi nilai sudut geser dan kedalaman fondasi dapat disimpulkan bahwa:

1. Perbandingan hasil perhitungan daya dukung ultimate secara manual dengan program memperoleh persentase perbedaan yang berkisar antara 0,06 - 41,09\% dengan persentase perbedaan terbesar oleh metode Terzaghi dengan kedalaman fondasi 1,5 meter dengan nilai sudut geser $20^{\circ}$ dan beban sebesar $301,64 \mathrm{kN} / \mathrm{m}^{2}$. Nilai dari daya dukung ultimate yang dihasilkan oleh program selalu lebih besar dibandingkan nilai daya dukung ultimate dengan perhitungan manual yang mungkin disebabkan oleh metode pendekatan analisis yang berbeda.

2. Berdasarkan hasil analisis perbandingan daya dukung ultimate terhadap variasi nilai sudut geser pada fondasi bujur sangkar dan persegi panjang pada kedalaman $1 \mathrm{~m}$ dan 1,5m, Semakin besar nilai sudut geser maka semakin besar pula nilai dari daya dukung ultimate dan penurunan elastisnya. Selain itu dapat disimpulkan juga bahwa semakin besar nilai sudut geser, maka semakin kecil nilai dari persentase perbedaan antara perhitungan manual dengan program.

3. Berdasarkan hasil analisis perbandingan nilai daya dukung ultimate dengan variasi nilai kedalaman fondasi bujur sangkar dan persegi panjang pada sudut geser $20^{\circ}, 25^{\circ}$ dan $30^{\circ}$, Maka dapat disimpulkan bahwa semakin dalam sebuah fondasi, Semakin besar pula nilai daya dukung ultimate dan penurunan elastisnya. 
4. Perbandingan nilai daya dukung ultimate terhadap bentuk tapak fondasi pada program dan manual memperoleh daya dukung fondasi berbentuk persegi panjang lebih besar dibandingkan bujur sangkar dengan persentase perbedaan pada metode Meyerhof yang berkisar $9-14 \%$ dan $1-5 \%$ pada program. Maka dapat disimpulkan bahwa bentuk tapak fondasi dengan luas yang sama tidak menyebabkan perbedaan yang besar.

5. Berdasarkan hasil analisis perbandingan penurunan elastis pada tepi dan tengah fondasi pada program, maka dapat disimpulkan bahwa terdapat perbedaan yang sangat kecil dengan persentase perbedaan kurang dari $1 \%$ dikarenakan fondasi bersifat kaku.

\section{Saran}

Dari hasil analisis yang telah dilakukan, penulis memberikan beberapa saran untuk melengkapi kekurangankekurangan yang ada, antara lain:

1. Melakukan analisis dengan program lain untuk membandingkan dan melengkapi kekurangan-kekurangan yang ada pada program berbasis metode elemen hingga.

2. Melakukan survey di lapangan dan membandingkannya supaya data yang didapat menjadi lebih akurat.

3. Perlu dilakukannya uji laboratorium agar didapat parameter dan karakteristik tanah yang lebih akurat.

4. Perlu dipelajari lebih dalam mengenai program berbasis metode elemen hingga yang digunakan.

\section{DAFTAR PUSTAKA}

Bowles, Joseph E. Analisis dan Desain Fondasi jilid 1 edisi keempat. Jakarta: Erlangga, 1992.

Budhu, Muni. Soil Mechanics and Foundation (Third Edition). New Jersey: John Wiley \& Sons, Inc., 2010.

Conduto, Donald P. Foundation Design Principles and Practices second edition. New Jersey: Prentice-Hall. inc., 2001.

Das, Braja M. Fundamentals of Geotechnical Engineering third edition. Spain: Chris Carson, 2007.

Desai, Chandrakant S. dan John T. Christian. Numerical Methods in Geotechnical Engineering. New York: McGraw-Hill, 1977.

Felenius, Bengt H. Basic of foundation design. Canada: Rothesay Avenue Sidney, 2014.

Hardiyatmo, Hary C. Teknik fondasi 1. Jakarta: PT Gramedia Pustaka Utama, 1996.

Badan Standardisasi Nasional. Standar Nasional Indonesia 8460:2017 tentang perancangan geoteknik. Jakarta: Badan Standarisasi Nasional, 2017. 
